\title{
Marginal Life
}

\section{Experiencing a Medieval Landscape in the Periphery}

\author{
Karin Altenberg
}

\begin{abstract}
Medieval landscape archaeology has mainly focused on the function and management of medieval settlements and their immediate surroundings. While theories concerning the experience of the cultural landscape, regional identity and social structure have proved fruitful in other disciplines such as prehistoric archaeology and human geography, medievalists have disregarded the possibilities of phenomenology for landscape studies. The wealth of materiel available to medieval landscape studies ought to be fully exploited in the development of theories concerning the experience of the landscape during the Middle Ages. Evidence from Bodmin Moor and Dartmoor in south-west Britain is re-examined in order to discuss the ways in which the landscape was perceived by those who lived and worked on the moors and by those who had an interest in the moors from further afield.
\end{abstract}

Karin Altenberg, Department of Archaeology, University of Reading, Whiteknights, RG66AA Reading, Berkshire, UK.

Key words: medieval archaeology, landscape, deserted settlements, phenomenology, marginality.

\section{INTRODUCTION}

Medieval landscape archaeology has lagged behind in the theoretical discussion carried out within British and Scandinavian prehistoric landscape studies during the 1980s and 1990s. Although the tradition of landscape archaeology has developed alongside that of cultural geography, it has followed the path of agrarian and local history rather than profiting from the post-modernist discussion conducted within the discipline of geography. While prehistoric landscape archaeology has developed theories of the social use of space $^{1}$ and the human perception of the natural and cultural landscape (e.g. Bradley 1993; Thomas 1996; Gosden 1994), medieval landscape archaeology has focused mainly on the settlements themselves (often high-status sites) and the management of their immediate surroundings (e.g. Beresford 1979; Beresford \& Hurst 1990).

\footnotetext{
'A range of different models have been tested in spatial studies, mainly in the fields of burial archaeology (e.g. Dommasnes 1987; Gansum et. al. 1997), artefact patterns (e.g. Welinder 1992 b) and settlement architecture and organisation (e.g. Parker Pearson \& Richards 1994; Cassel 1998)
} 
This article will argue that medieval archaeology can benefit by adopting ideas about the experience of the landscape from the discourses of phenomenology and temporality, which are frequently used within prehistoric landscape archaeology (cf. Tilley 1994) to shed light on issues such as the perception of space, time and identity. Moreover, it will be argued that a multidisciplinary approach, using data from the Sites and Monuments Records and excavation reports along with historical and folklore evidence, may increase our understanding of the perception of the medieval landscape and strengthen the argument for phenomenology.

\section{THE POTENTIAL OF MEDIEVAL ARCHAEOLOGY}

Occasionally, as we walked, we'd stumble over slightly elevated grassy square shapes, 'medieval' Chris said. Most times I didn't even notice them. Equally, I guess I wouldn't have noticed the stone row. Such very small stones, and half covered in grass. A strong sense of not 'seeing' much...(Bender et al. 1997:158)

These lines from the 'field diary' kept by the members of the ongoing Leskernick project on Bodmin Moor in south-west Britain show that the perception of the landscape is very individual and that it is difficult for the archaeologist to look for the 'right' views, that is those visual relationships that were important and interesting to the prehistoric or medieval farmer on Leskernick Hill. In the case of the Leskernick project, this has been called the problem of 'swivelling'. ${ }^{2}$ When Tilley and his team looked out of the wooden door frames at Leskernick and 're-experienced the past' in the visual relationship between a Bronze Age hut and a distant "tor" (i.e. a rocky outcrop or peak with a characteristic shape in the Bristish highlands), they were interested in the ritual aspects of life. However, if they had let their eyes drop and 'swivelled' a bit lower, they would also have seen the fields and pasture, a view of perhaps equal importance to the inhabitants of the hut-circles.

Although I find the phenomenological approach outlined by Tilley (1994) very interesting, its application to the landscape of Welsh megalithic tombs ${ }^{3}$ or the hutcircles at Leskernick is very problematic, mainly because of the haphazard way in which relationships are invented between features in the landscape in order to fit the theoretical point of departure: "Lacking any tangible material evidence at present it is, of course, impossible to recognize exactly which of the Tors and rock outcrops had an especial significance to Mesolithic populations, but it seems likely that particularly striking topographical features and high craggy eminences would have been of great importance" (Tilley 1995:12).

\footnotetext{
2 One part of the landscape survey at Leskernick involved looking out of hand-made wooden door frames in order to record the views from the hut-circles and "in order to think about the house entrances and what the people of Leskernick would have seen as they moved out of their doors". In this process Chris Tilley suggested that the viewer must not swivel with the eyes but look straight ahead in order to get the perfect prehistoric view (Bender et al. 1997:166).

${ }^{3}$ For a critique of the fieldwork evidence in A Phenomenology of Landscape see Fleming (1999) and Lynch (1996).
} 
However, the interpretation does not become valid just because Chris Tilley finds it likely. This kind of ungrounded subjectivism is not acceptable in the archaeological discourse, which needs to be based on a recognisable set of data. The problems with the application of the model can be summarised in three points.

First, Tilley's model cannot be replicated by anyone else as it is very much based on Tilley's personal perception and interpretation of the landscape. This has been clearly demonstrated by Andrew Fleming in his reinterpretation of Tilley's survey of megalithic tombs in Wales (Fleming 1999). Also, once it has been established that a certain landscape was experienced as meaningful and ritual, one has to develop a model to consider why and in what ways; otherwise, it is a pointless statement.

Second, the model is limited to the study of monuments and their presumed ritual purposes rather than to the landscape of Leskernick Hill or the Black Mountains, while the changing use of monuments as indicated in excavations (cf. Bradley 1990) is ignored.

Third, visual impressions are over-represented in relation to other forms of experience. There are probably practical explanations for this, but this was not what was envisaged in the manifesto of archaeological phenomenology in 1994. The study of sound in a landscape could be fruitful, as sound is important for orientation and the perception of space (cf. below).

Through documents and ethnographic sources, medieval archaeologists are given the advantage of finding out where the people of the past may have been directing their gaze - what was worth looking at and what was easily, and sometimes deliberately, ignored. It is important to emphasise that, unlike the prehistorian, the medieval archaeologist has access to evidence of how the surrounding landscape and monuments were perceived as well as documents to support the excavation reports. Such sources, which are often considered restrictive for archaeological interpretation, may actually open up new and fruitful possibilities for the writing of archaeology. David Lowenthal expresses this as follows:

"Memory, history, and relics offer routes to the past best traversed in combination. Each route requires the others for the journey to be significant and credible. Relics trigger recollection, which history affirms and extends backwards in time. History in isolation is barren and lifeless; relics mean only what history and memory convey. Indeed, many artefacts originated as memorial or historical witnesses. Significant apprehension of the past demands engagement with previous experience, one's own and others', along all three routes" (Lowenthal 1985:249).

\section{ARCHAEOLOGY, HISTORY AND PHENOMENOLOGY}

"Without habit and the memory of past experience, no sight or sound would mean anything..." (Lowenthal 1985:31)

It would be a great mistake for both prehistoric and historic archaeology to neglect the influence of history on the experience of self and the landscape. In line with Hodder's rediscovery of history in the early 1980 s, a historical approach in this case encompasses the idea of sequence and continuity rather than the actual written word. Hodder (1987:1, 
1986) describes this as "identifying the series of events that lead up to the event to be explained."

As archaeologists we must be prepared to describe this sequence of events in order to answer the question of why something was in a certain way at a certain point in history. This idea can be compared to Geertz's concept of 'thick description'. Geertz uses thick description as a means of conducting ethnography and understanding culture contextually. It is a way to dissect the multiple background of a context and order the mixed and superimposed sequence of events (cf. Geertz 1975).

The context of a specific archaeological moment (a phase in the stratigraphy, the desertion of a settlement, etc.) is therefore partly illuminated by historical and ethnographic records of preceding or contemporary events.

In the same way history, which is vital for the construction of society, was used in the past to legitimate status and power or to explain the present. Knowledge of the past, that is the generation of events, ideas, views and behaviour, shaped the identity of individuals and groups. Geertz (1975:52) puts it in this way: "Becoming human is becoming individual, and we become individual under the guidance of cultural patterns, historically created systems of meaning in terms of which we give form, order, point and direction to our lives".

The 'thickly described' historical/cultural context as expressed in, for example, a folk-tale, can be compared to Bourdieu's concept of "habitus" as a collective way of life or as a 'learned ignorance', that is, a socialised way of behaving and speaking. The "habitus" determines the ways in which power is produced and reproduced and the ways in which a person gets access to or is secluded from "social space". Through the symbolic ordering of space and time we experience our role and place in society (Bourdieu 1977). Habitus thus influences regionality and cultural variation. Bourdieu minimises the value of the individual agency and stresses the impact and power of socialisation and groups.

Judith Butler (1993, 1997:532) has addressed this point more successfully in defining the concept of performance as the way in which identity is formed through the daily repetition of social or cultural norms in relation to an individual's bodily experience. Socialisation in this view is not only determined by the power imposed by the traditions and norms of a society, group or family, but individuals are also formed according to their perception of the self, for example, according to gender identity (cf. Gilchrist 1999).

The first step towards a phenomenological discourse in medieval landscape studies is thus to recognise the importance of the historical approach for the assessment of experience and identity in a past society. Moreover, it is essential to avoid the obsession with textuality which is characteristic of post-modernist studies and favoured within

\footnotetext{
${ }^{4}$ The textuality and structure theory discussed by Barrett is determined by the structured cultural codes which become meaningful through mobilisation and interpretation by social agents. In order for this to work the code, or the elements of the code, must be consciously known and understood by the interpreter (Barrett 1994:37, 75, 133).
} 
modern prehistoric archaeology (cf. Barrett 1994). ${ }^{4}$ The search for a text to be read, that is the "reading" of the landscape, inhibits the pluralism of the thick description and the contextual approach. The elements in the pattern that the archaeologist tries to establish are not ordered linguistically in meaningful structures but rather formed through the "unconscious generation of principles" (Harvey 2000:49). The pattern cannot be "read" but instead dissected through thick description.

\section{THICK DESCRIPTION OF A MEDIEVAL LANDSCAPE}

In the following I will try to show how the experience of a specific medieval landscape can be studied, using my own observations from the field, data from the Sites and Monuments Records, excavation reports, historical documents and ethnographic sources. I will present examples from a landscape survey of the medieval remains on Bodmin Moor in Cornwall, that is those 'grassy square shapes' that Tilley and his team tended to ignore. The evidence from Bodmin Moor will be compared to a similar set of data from nearby Dartmoor in Devon (Fig. 1).

Special attention will be given to the ways in which the perception of the landscape can be linked to regional and local identity and how social organisation is shaped by the relationship among memory (knowledge of the past), myth, identity and authority.

The advantage of medieval or any other form of historical archaeology over prehistoric archaeology in this respect is that we know more about medieval ideology and the influence of Christianity on medieval thinking. Religion emphasises continuity and legitimates itself by adapting the past for the purpose of offering an authoritative version of the nature of existence. Through religion the here and now is given a place in space and time.

The folk-tale can be very useful to a phenomenological approach as it is based on

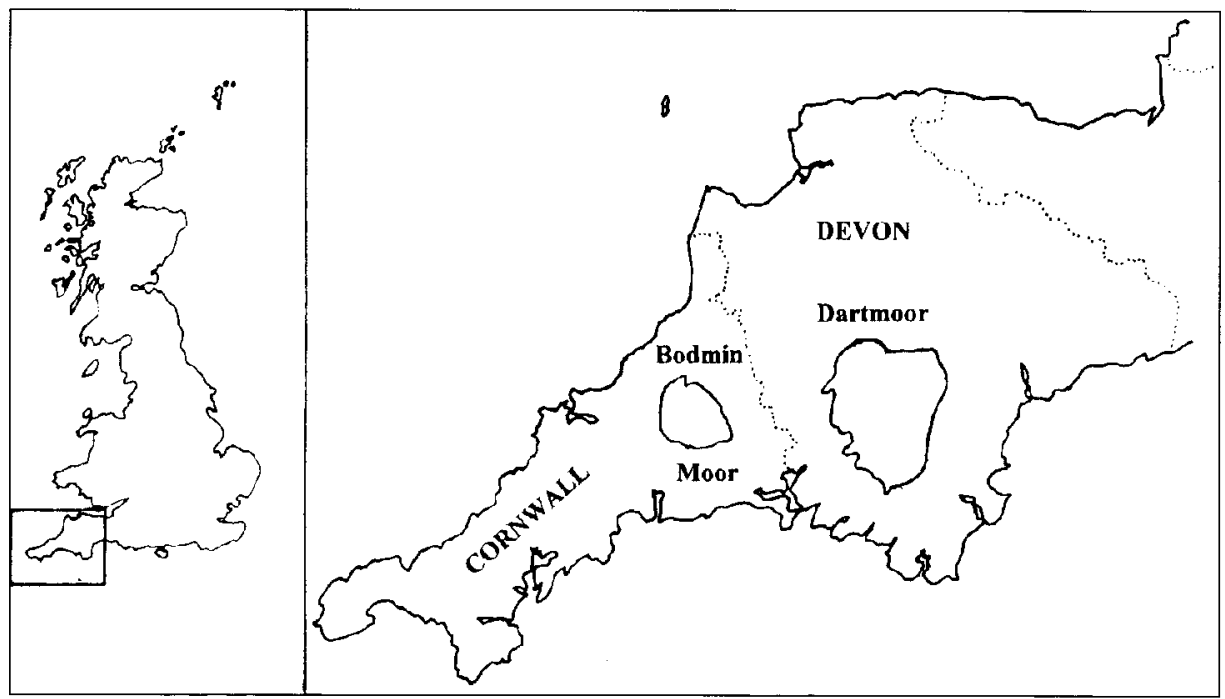

Fig. 1. Location of Bodmin Moor (Cornwall) and Dartmoor (Devon) in south-west Britain. 
human fear, an inability to understand certain elements of life and nature - and the need to explain them. It is an expression of the rituals and superstition that are frequently referred to in prehistoric archaeology. The folk-tale is the sister of religion (and indeed the one often carries elements of the other), a vernacular way of explaining our being in the world. Folk-tales are often concerned with unmappable and untimeable places. The exact co-ordinates and dates of an episode are not as important as the explanation of why it occurred (Genesis is an example of this). However, a folk-tale can also be directly connected to a place (rather than an event), in which case it is more likely to survive over a long period of time as stories of a local landmark will be passed on down the generations (cf. Zachrisson 1996). Such stories of medieval origin are common on Bodmin Moor and Dartmoor, and they are very important for the understanding of cosmology and superstition. These stories are usually concerned with explaining the existence and construction of monuments, with the climate and weather and with placenames, all specific to these landscapes. The main characters are usually local farmers or gentlemen, the devil, giants or saints. The problem is to identify who initiated the tale: was it the outsiders who were scared by the bleakness of the moor, or was it the local farmers who felt the need to tame and explain their surroundings? In any case, the location of this type of folk-tale is often understandable and recognisable - a fictive reflection of home. Alison Wylie (1985) has discussed the value of folk-tales for archaeological research as a form of "bounded analogy", and she promotes the use of multiple sources of analogy and a careful examination of the similarities and differences between the analogues, that is the compared contexts.

There are well-preserved tracks and drove roads on Dartmoor and Bodmin Moor, and documents and maps describe where and how people and animals moved through the landscape. We also know where they lived and how the farms were positioned in relation to each other, to natural features and to economic, political and religious centra. Ethnographic and folklorist sources of medieval origin sometimes tell us about the ways in which people perceived their surroundings, and what they were afraid of, why some places were preferred and others avoided.

\section{BODMIN MOOR AND DARTMOOR}

"On either side of the road the country stretched interminably into space. No trees, no lanes, no cluster of cottages or hamlet, but mile upon mile of bleak moorland, dark and untraversed, rolling like a desert land to some unseen horizon. No human being could live in this wasted country, thought Mary, and remain like other people; the very children would be born twisted, like the blackened shrubs of broom, bent by the force of a wind that never ceased, blow as it would from east and west, from north and south. Their minds would be twisted, too, their thoughts evil, dwelling as they must amidst marshland and granite, harsh heather and crumbling stone" (Du Maurier 1936:21).

Bodmin Moor in Cornwall and Dartmoor in Devon are two granite uplands with a similar physical character. The climate is relatively wet and cold with prevailing southwesterlies coming in from the Atlantic. Because of the climate and the acidic soil, the 


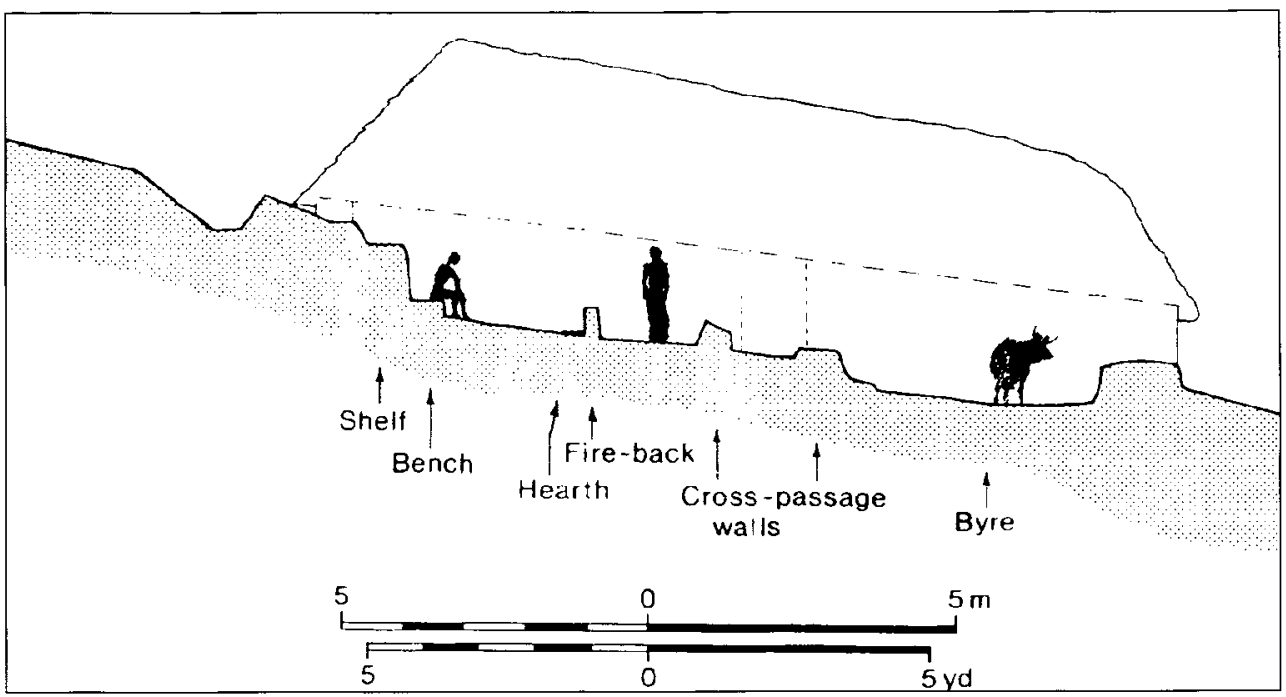

Fig. 2. Profile reconstruction of excavated longhouse in the deserted medieval settlement at Garrow, Bodmin Moor (Johnson \& Rose 1994).

moors were never particularly suitable for arable farming. The medieval settlement is dispersed, and although most hamlets and farms were situated in relatively sheltered locations in river valleys and on the slopes of the tors, their location was often very exposed. As the quote from Du Maurier's Jamaica Inn shows, the landscape with its spectacular tors and the windswept plains stimulates the imagination of the visitor. (Du Maurier's view of the landscape is obviously not medieval, but influenced by the wild, dramatic and almost spiritual landscape view of the British romantic tradition.)

After a period of arable farming on the moors during the Bronze Age, the area was not permanently settled until the Middle Ages. According to place-name evidence, excavated material and historical sources, most of the deserted medieval settlements seem to have been established in the $12^{\text {th }}-13^{\text {th }}$ centuries. ${ }^{5}$ The hamlets normally included two to six farms, where each farm typically consisted of a longhouse shared by humans and livestock. The longhouse was constructed downslope to improve the drainage. It usually consisted of two or three parts: the shippon or byre end situated downslope, the living area upslope, and a third room which was often situated above the central living area (Fig. 2). Sometimes rooms were added to the longhouses in a later phase. The longhouse was often associated with a small ancillary building and/or a corndrying barn.

The medieval farmers practised small-scale arable cultivation and animal husbandry. A number of settlements were deserted or had shrunk towards the end of the Middle

\footnotetext{
5 Three medieval longhouse settlements on Bodmin Moor and six on Dartmoor have been partly excavated. A chronology of the pottery from several sites on and around both moors was published by Allan in 1994, and a substantial survey of the prehistoric and medieval landscape of Bodmin Moor was undertaken by the Royal Commission and the Cornwall Archaeological Unit and published by Johnson \& Rose in 1994.
} 
Ages, and as there has not been any extensive ploughing on the moors since then, the traces of the medieval farms, fields and boundaries survive on the ground.

The deserted medieval villages on Bodmin Moor and Dartmoor have traditionally been seen as expressions of a general tendency related to farming in marginal areas of medieval Britain, where the outlying land was settled during periods of population pressure on the better land and subsequently abandoned when the population and the climate declined (cf. Postan 1972; Taylor 1992; Beresford 1979. See Dyer 1990; Astill \& Grant 1988; and Astill 1997 for critique of this view). Judging from the similarity of the material culture, in particular the remains of vernacular architecture and pottery recorded from the excavated sites (no organic material has survived in the acidic soil), my initial impression was that the settlements on the two moors were very similar - as if there was a cultural idea of what a longhouse settlement should be like. However, a closer look at the variety and quality of the excavated artefacts suggests that status was expressed inside the buildings rather than in the size of the farm and the number of outbuildings. Another interesting feature is that every longhouse on Bodmin Moor has an associated, enclosed garden or pound. This arrangement seems to have been a defining feature of the Bodmin Moor longhouse. Moreover, the more I came to know the area and the landscape of the sites, the more I realised that the perception of the landscape in the two areas may have been very different in some respects mainly because of ownership rights. I therefore decided to study the landscape from two contrasting perspectives: from within and from the outside. The perspective from within is that of the people who lived and worked in the area, and the perspective from the outside is that of the people who exploited the moors in some way from further away (manorial, monastic, merchants). This terminology should not be confused with the relation between the perspective of the people of the past and the perspective of the modern researcher. The perspective from the outside will be discussed first ${ }^{6}$.

\section{THE PERSPECTIVE FROM THE OUTSIDE}

It is clear that the secular landlords in the area viewed the moors differently from the Catholic church. The ownership rights on both moors were organised around two main resources - tin mining and pasture - which created different visible and invisible boundaries. Bodmin Moor was divided into four hundreds (Trigg, Lesnewth, East and West Wivelshire) already in the pre-Norman period (Herring 1986; Johnson \& Rose 1994). The structuring of the hundreds and the parishes around Bodmin Moor seems to have been the result of an effort to exploit the good pasture on the unenclosed common land, and the four hundreds around Bodmin Moor all stretched from the moor to the coast. It has been suggested that each hundred had its own large pound where cattle could be rounded up. Some of them survive in the landscape today: Stowe's Pound, East Wivelshire, Crowpound, West Wivelshire, and perhaps 'King Arthur's hall' near Garrow in Trigg hundred (Herring 1986:127-130) (Fig. 3). These pounds, together

\footnotetext{
"The evidence of the internal and external organisation of buildings and farmyards will be discussed elsewhere (Altenberg, forthcoming).
} 
Fig. 3. The hundreds of Lesnewth, East and West Wivelshire and Trigg reaching onto Bodmin Moor, and the possible hundred cattle pounds in Trigg and East and West Wivelshire.

with a few shielings and so-called beehive huts, are the only visible material remains of a probable Iron Age and Early Medieval cooperative transhumance system. Iron Age and Early Medieval place-name evidence of hendre ('winter farmstead') and havos ('summer dwelling') sites on and

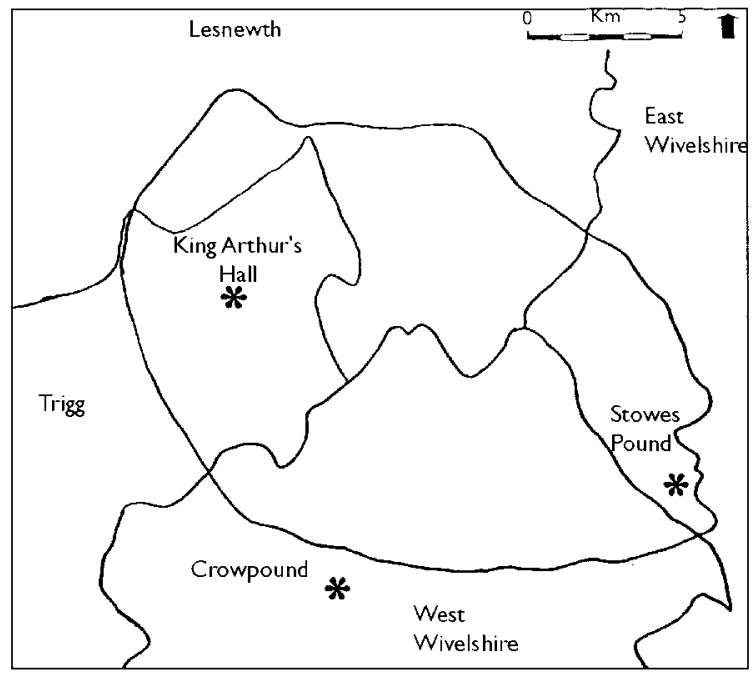
around the moor supports the idea of an organised transhumance system (Padel 1985).

In the later Middle Ages, during the period of the medieval settlement on the moor, the grazing was organised on a manorial or parochial level, as indicated by the distribution of drove roads leading from the cores of the parishes or manors and onto the moor. This is especially clear for the parishes bordering on the Fowey valley and for the border between St Breward and Blisland along the De Lank River. Documents refer to a manorial organisation of pasture. In 1284, the pasture on Twelve Men's moor on eastern Bodmin Moor could be enjoyed by the tenants of Caradon Manor (gift deed from Launceton Prior to twelve named tenants, Hull 1987:208-209). The free and customary tenants of Blisland Manor could freely use the pasture on the 'outmoores' in 1597 (Maclean 1868:88). The farms on the moor were often very isolated, they paid low rents and had little contact with their manors, which were often more than a day's walk away (see below).

The situation on Dartmoor was distinctive, as the central part of the moor had been a Royal Forest since the Norman invasion and probably even earlier (Crossing 1994:11). Three pre-Conquest charters ${ }^{7}$ define areas with land reaching up towards the moor (Hooke 1994). During the later Middle Ages, when settlement was well established within the area, special regulation determined how people living within the forest or in the parishes adjoining it could use the pasture within its boundaries. A description of the organisation of the pasture on Dartmoor dividing the area into concentric circles has survived in a document from the Tudor period, but the system and terminology go back to earlier $13^{\text {th }}$ - and $14^{\text {th }}$ - century documents from the moor (Fogwill 1954; Wurth 1944). Using concentric circles was a common way of organising the world in medieval

\footnotetext{
${ }^{7}$ The Crediton charter of 739 , the Meavy charter of 1031 (this charter describes the "hay (waggon) way of the people of Buckland", indicating a route from Buckland Monacorum to the pasture on the moor) and the undated Peadingtun charter.
} 


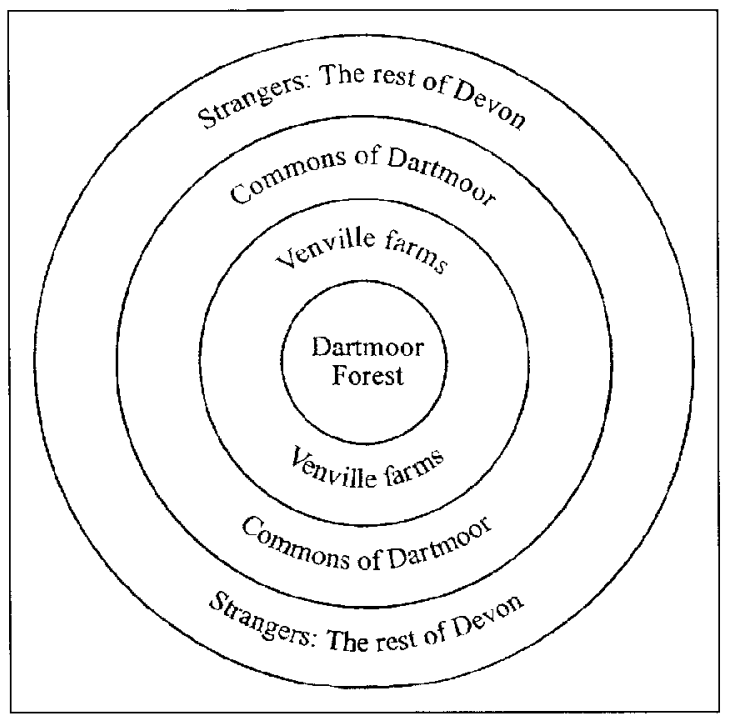

Fig. 4. The Tudor model of the organisation of pasture on and around Dartmoor.

mentality, as reflected in Dante's Divina Commedia, Bede's De Natura Rerum and Copernicus' model of the solar system, and it reflects the limited horizon of medieval map makers. The model also illustrates the different standpoints of the involved parties as the perspective changes from viewing the moor from the centre or the periphery of the medieval world (Fig. 4). The innermost circle represented the royal forest and the rights of the so-called ancient tenants who were allowed to keep tenements within the forest by freehold. The second circle included the commons of Dartmoor, that is the land between the forest boundary and the enclosed land. The commons were used by the parishes and manors surrounding the moor. The third circle was made up of the villages and hamlets with so-called venville rights (i.e. certain settlements around the moor which paid rents in order to keep their stock on the commons and in the forest and extra night rest which could be paid to leave the stock in the forest over night). The last circle was made up of the outsiders or strangers; the people of the rest of Devon who had to pay rent to graze their stock on the commons. ${ }^{8}$ It is clear from the terminology of the document and from the status of the inhabitants of the different circles that Dartmoor was seen as very central in relation to grazing and that the ancient tenants at the core of the forest enjoyed a special status.

Whereas Dartmoor had a relatively high proportion of arable land, Bodmin Moor had a higher proportion of land in pasture and waste from the thirteenth to the sixteenth century (Fox 1991:154). There is no evidence of single farms or purely pastoral farms from Bodmin Moor during this period (Herring pers. com.).

From an economic and political perspective, Dartmoor was perceived as relatively central as it was incorporated into a secular system of power and status concerned with access to resources and the exhibition of ancient royal privileges. A large number of markets developed around Dartmoor, which was soon incorporated into Exeter's trading network. The large number of seasonal fairs held in the autumn $(40 \%$ of the fairs in the Dartmoor region) demonstrates the impact of Devon's and Cornwall's pastoral economy and the importance of transhumance, as the stock could be sold and fattened before slaughter (Kowaleski 1995:42-45). The annual drifts on Dartmoor took place around

\footnotetext{
${ }^{8}$ The term extranei is known from a document of 1381-2 describing the men of Devon who were not venville or forest men (Worth 1944:207).
} 
Midsummer throughout the Middle Ages, which may explain why fairs were also held in June and July (i.e. before the grazing period was over) in five major villages around the moor - Bovey Tracy, Buckland Monacorum, Lydford, Moretonhampstead and Okehampton (ibid. 353 ff.) - whereas no fairs were held in May (i.e. before the grazing period started and before the annual drift). On Bodmin Moor the situation was different as the grazing was organised on a more local level by manors and parishes, and the markets developed at natural meeting places such as church villages and manors and were never directly incorporated into Exeter's economic hinterland. Bodmin Moor thus seems to have been less central than Dartmoor.

St Michael was the patron saint of Cornwall with feast days on the $29^{\text {th }}$ of September (Michaelmas) and the $8^{\text {th }}$ of May. These dates indicate the strong connection between the saint and pastoral activities, and the feast days are often mentioned in relation to grazing rights and transhumance. Both Devon and Cornwall had a very large number of dedications to St Michael, with a strong concentration in North Cornwall (30\% of the county's recorded St Michael dedications) and East Devon (30\% of the county's recorded St Michael dedications). ${ }^{9}$

So far, I have tried to show that the traditional image of the medieval moors as economically marginal is partly invalid and that the areas were perceived as quite central from a secular, medieval perspective. However, the moors were definitely seen as marginal from a Christian perspective. They were outside Christian civilisation. As late as 1523 , the priest in Crediton, near Dartmoor, sent a letter to the bishop of Exeter complaining that some of his parishioners only came to mass four times a year (Aston 1990). This was a common offence as most settlements were separated from their parish churches by more than 5 kilometres of rough moorland. On Bodmin Moor aspects of the old Celtic church lingered, as shown by the number of holy wells dedicated to Celtic saints (Fig. 5). There were no monasteries around Bodmin Moor, and there is evidence that people worshipped at springs and monuments in the landscape rather than in church during the Early Medieval period (Orme 1991). On the Dartmoor border, which was closer to Exeter and the national diocesan system, three Cistercian abbeys were established in order to benefit from the seclusion of the liminal zone and to control large areas of pasture. In folklore Bodmin Moor and Dartmoor are described as areas inhabited by trolls, giants and the devil, and place-names especially on Dartmoor often incorporate the element Satan or "grim", which is the Saxon name for the devil.

In order to tame the wilderness a number of Christian monuments (stone crosses and chapels) were erected on both moors throughout the Middle Ages. The stone crosses had a dual purpose - they guided the travellers across the moors and marked the presence of Christianity. Sometimes they marked boundaries. The monasteries and parish churches around Dartmoor were linked by lines of stone crosses, and at least eleven chapels stood on the border between the enclosed land and the open moor, some of them by the moor gates (Fig. 6). These are interesting positions, as the forest carried the image of fear and disorientation in medieval symbolism. The word "forest" comes

${ }^{9}$ These figures have been collected from the National Sites and Monuments Record (NMR) in Swindon. 


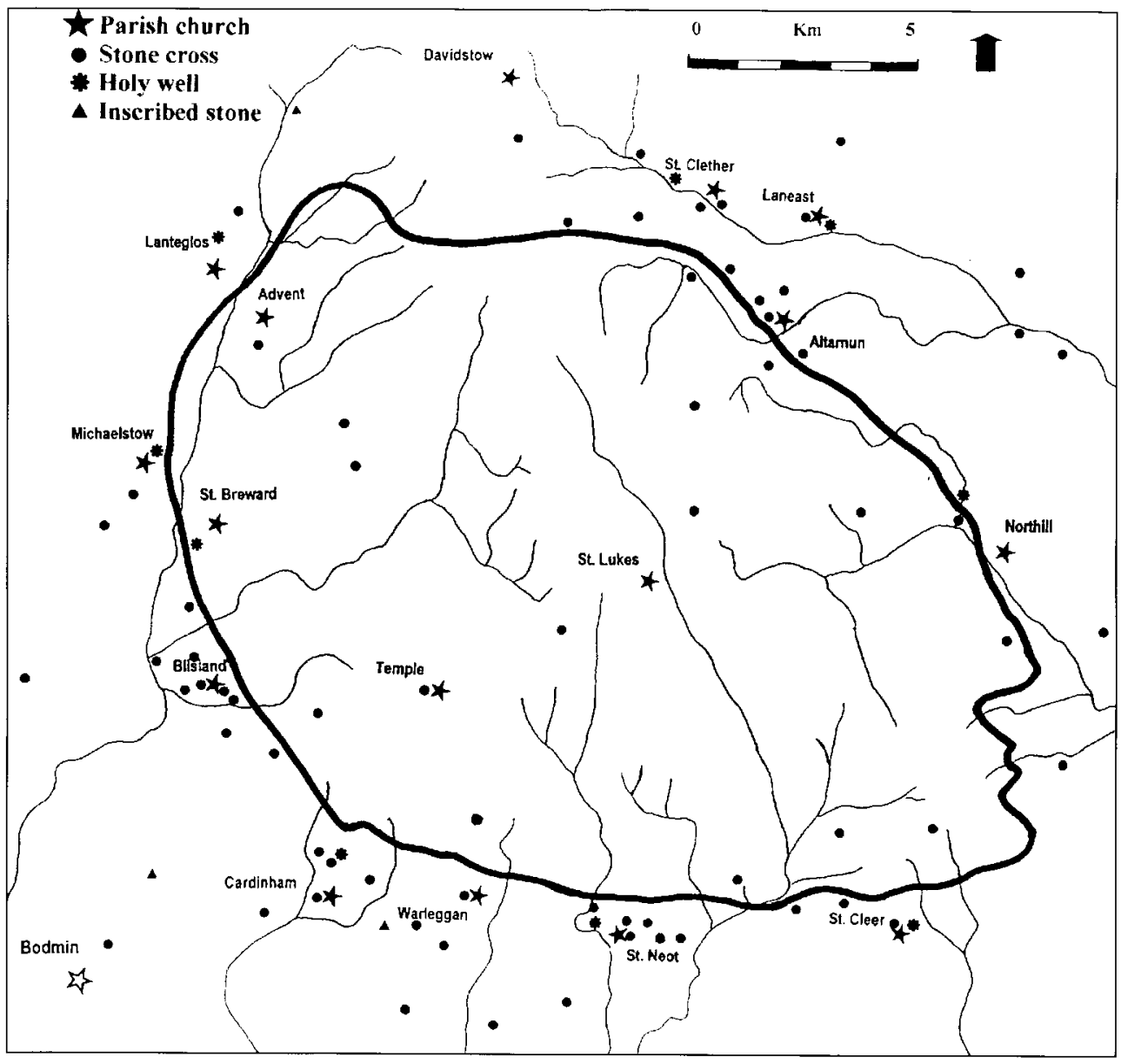

Fig. 5. Distribution of stone crosses and holy wells around Bodmin Moor. The row of crosses from Altarnum to Blisland via St. Lukes and Temple almost coincides with the route of the modem dual carriage way (A 30).

from the Latin foris meaning 'outside bounded space' or 'out of door' (the same as in "foreigner"). A similar way of placing a ritual (?) monument in the liminal zone between enclosed and unenclosed land is perhaps manifested in the distribution of Gotlandic picture stones (Andrén 1989; Burström 1994).

On Bodmin Moor the perception of the wasteland seems to have been slightly different, and it is interesting to assess the visual phenomenological aspects of the location of the chapels. The impact of the visual sense is vital for the experience of a landscape. Eighty per cent of our perceptual intake is visual, and although we can hear, smell and feel the world around us it is to a large extent with our sense of vision that we are able to construct a system of orientation (cf. Porteous 1990). The medieval chapels were not placed in the liminal zone between the moor and the enclosed land as on Dartmoor, but rather in symbolically significant places on the moor itself. The 


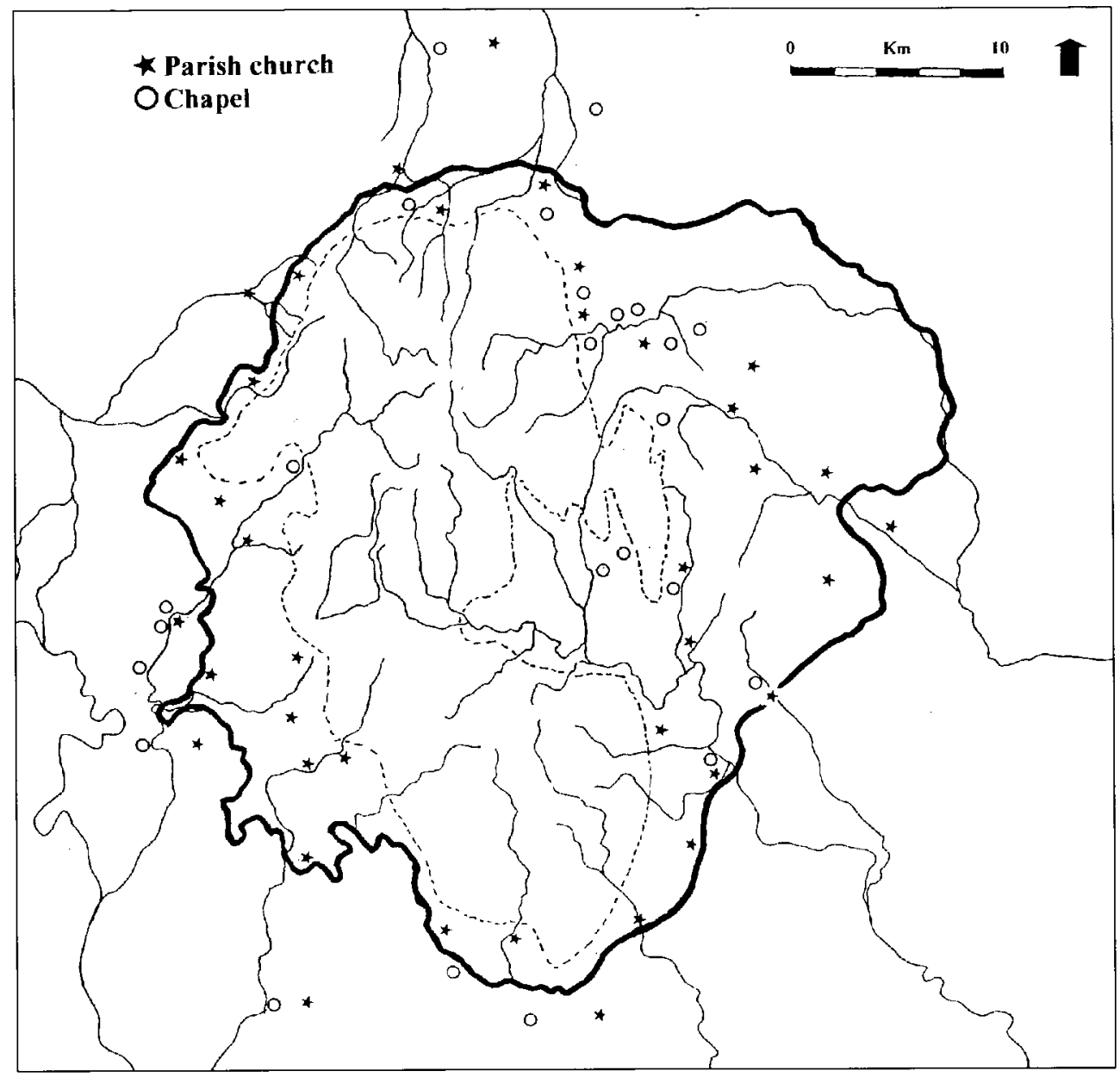

Fig. 6. The location of medieval chapels on and around Dartmoor: The broken line marks the approximate outline of the enclosed land (Source: The Ordnance Survey Map and Devon SMR)

location of the chapels was a clear manifestation of the presence of Christianity in the uncivilised area. St Michael's and St Bellamin's were constructed on top of spectacular tors and St Luke's and St Petroc's in the upper parts of river valleys. According to Higuchi (1983: 136-144), both are typical places for ritual monuments. The first case represents the "Sacred Mountain' type of landscape, of which there are many examples from the area. These tor chapels were normally dedicated to St Michael and often constructed as part of the rock, as if the builders wanted them to be part of nature (Figs. 7 - 8). The second case represents the 'Secluded Valley' type of landscape, where the chapels were situated in the upper reaches of a river valley or by the source of a river. According to Higuchi, the shape of the valley draws the viewer into its secluded space and serves as a passageway between the secular and the sacred. The valley leads downstream to civilisation.

A local tradition says that Temple Church, erected by the Knights Templar on central 
Bodmin Moor, was built in order to civilise the wild men of the moor and that women who merited seclusion were sent to Temple Church. The local saying "send her to Temple moors" was last recorded in the $19^{\text {th }}$ century as something that was said about a social outcast, especially loose women (Hunt 1871:440). There seems to have been a strong desire to civilise and perhaps incorporate the people on the moor into the parishes on the lowland. The moor was perceived as marginal and the efforts of the church were missionary as it tried to include the moor in the civilised society. On Dartmoor, on the other hand, the task of the church was to mark the boundary between the wasteland and the enclosed land and to protect its civilised parishioners from the mythical inferno of the foris.
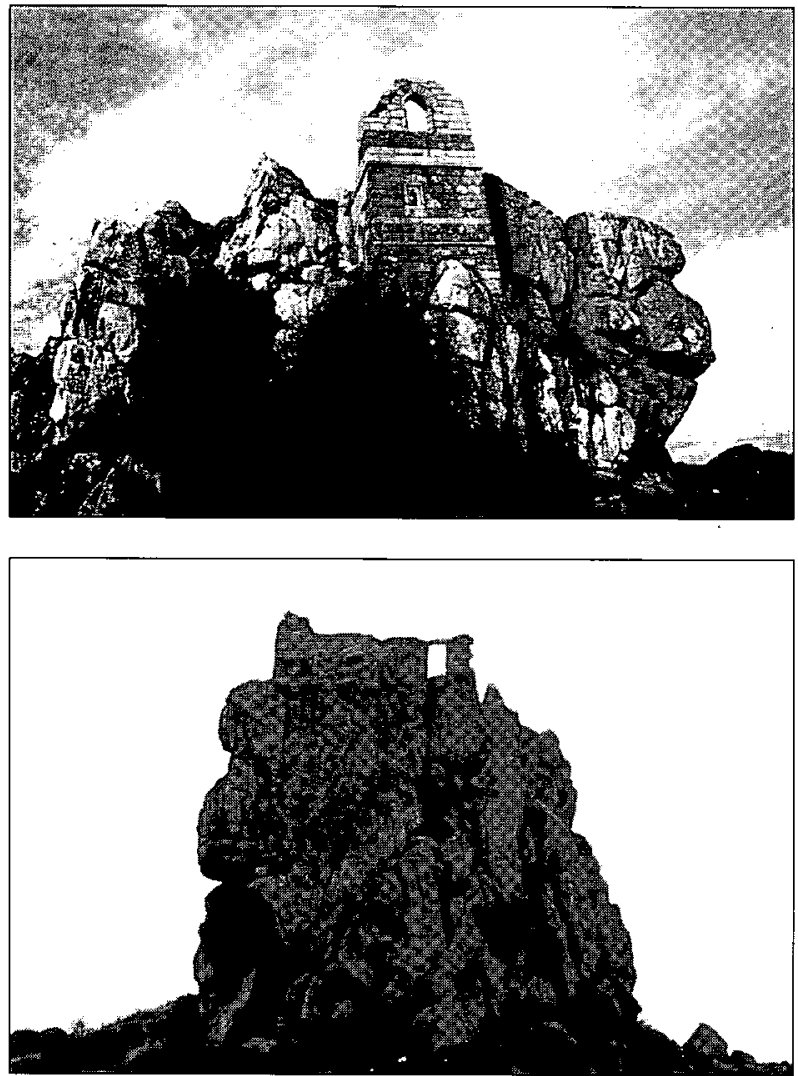

Fig. 7 - 8. Sacri Monti: the remains of St Michael's chapel at Roche Rock. Cornwall. Photo: K. Altenberg.

The chapels and stone crosses were erected in a mental crusade against the unknown. On both moors the religious elements in the landscape were dependent on and appealed to the visual sense. A direct visual impact was needed in the landscape if Christianity was to be perceived as superior to nature and therefore convincing and comforting.

The reason for this difference in the motives of the church in the two areas may be explained by the fact that every parish around Bodmin Moor included rough moorland that could be settled. On Dartmoor, by contrast, the roughest part of the moor was made up of the forest and commons and the parishes mostly consisted of enclosed land, so that there was already a perceptual boundary between the enclosed and the outlying land. This shows the power of the church in the creation of local cultural identity.

\section{THE PERSPECTIVE FROM WITHIN}

The perspective from within is concerned with the importance of distance and with how the medieval farmers in the area perceived their surroundings, especially the spectacular natural features and prehistoric monuments on the moors. 
All but one of the deserted medieval settlements that I have studied on Bodmin Moor are within a 50 metre radius of a prehistoric feature, normally a boundary, field or structure. The medieval settlements usually overlook pasture and face away and downhill from the prehistoric settlement remains. This relationship between prehistoric and medieval remains is not so consistent on Dartmoor. The reason for this is unclear, but it could indicate a slightly later colonisation phase as some of the earliest medieval settlements on Dartmoor incorporate prehistoric features. It has been argued that the prehistoric boundaries and features on Holne Moor on Dartmoor were ignored by the original medieval settlers, whereas they were incorporated into the later medieval settlement structure (Fleming \& Ralph 1982). Perhaps the prehistoric boundaries were adapted in the first period of colonisation in order to create a link backwards in time and thus legitimate the reclamation of new land. Later, when settlement was already established on the moor, the reverence for the prehistoric structures may have ceased and the new settlers may have ignored or destroyed the earlier features in order to construct their own, individual farms and new-takes. Alternatively, the process of diabolisation (mentioned below) may have become stronger as the church gained ground in the areas. This may have been another reason for stripping the prehistoric settlement structures of their ancestral meaning in the later phase.

The Bodmin Moor settlements are almost always situated in close relation to a spectacular tor, whereas this is not necessarily the case on Dartmoor. What is clear in both cases is that the medieval settlers must have been aware of the presence of earlier structures in the area; they were not pioneers and must have wondered about the landscape, which presents one of the best preserved areas of prehistoric monuments and settlements in southern Britain. Although in the Bronze Age, and to some extent the Iron Age, field boundaries were reused by medieval farmers, the hut-circles were seldom adapted for living purposes. Instead the monuments were carefully preserved in the landscape, and local folklore incorporated the monuments into the mythology of the community, sometimes inventing curses for those who tried to destroy them (cf. Hunt 1871:300).

A number of medieval drove roads and tracks survive on the moors, and the inhabitants of the settlements often had to walk many miles in order to bury their dead in consecrated ground. The dead were to be carried on special routes, preferably not new roads and not roads used by animals (cf. Crossing 1912 (1993)). One such path, the Lich Way (lich=Sw. lik), can still be traced on Dartmoor. Its use is indicated in a document from 1260, in which the ancient tenants of Dartmoor forest pleaded to the bishop of Exeter to let them use the church at Widecombe instead of their parish church in Lydford, which was 8 miles further away on a good day and 15 miles further away on a stormy, wet day when the fords were flooded. The medieval farmers in the 'marginal' areas knew that trade and exchange implied movement over time. In a household economy with varied production and in which labour was essential for survival, one was also aware of the price of time, that is the loss of income when travelling to a market or to church. For people following the Lich Way the tors must have been indispensable orientation points. The tors were important landmarks in a landscape 
which was otherwise characterised by a monotonous repetition of itself. Local people would be able to distinguish the shapes of the different hilltops and rock formations and use them to orientate themselves in the landscape, and many tors are mentioned by name in the medieval boundary charters. The documents also show that the inhabitants of the moor considered their surroundings to be rough and dangerous, as demonstrated in a letter from the tenants of Babeny and Pizwell to Bishop Bronsecombe, or in the early medieval legend of Childe the Hunter where a man is caught in a blizzard on Dartmoor and dies even though he takes cover inside the stomach of his dead horse (Finberg 1952: $40 \mathrm{ff}$.).

In a landscape where occupation was varied and the control of stock was essential, it was important to know the boundaries (actual or mental). The boundaries symbolised ownership rights and the reclamation of land from nature. They protected the reclaimed land from the chaos of the outlying lands and helped to structure the medieval world according to principles of inside and outside and private and communal ownership. The boundaries of the Dartmoor parishes were strictly maintained, and the 'Beating of the Bounds" between enclosed and common land was an annual occasion. It was a physical manifestation: everyone was supposed to attend and to experience the bounds in order to give them legitimacy. The physical process of Beating the Bounds was like a legal document, and the keeping of the bounds was therefore enforced by strict laws and regulations, where the task of the community was to keep the memory of the markers. The territory of the parish was recreated through the Beating of the Bounds, and it is interesting to note that most of the Dartmoor beatings happened in the spring - the time of recreation. It was especially important that children were present, so that they could be initiated into the knowledge of the bounds. By moving along the boundaries in the landscape the inhabitants of the parish or village were given a social identity. The boundary markers were often natural features or prehistoric monuments. In 1672 the Mayor of Okehampton described in his diary the annual Beating of the Bounds (quoted in Crossing 1994:51). He notes that both old and young had gathered for the event. The party went around the bounds, stopped at every marker and said its name aloud. When the boundary passed a stream or a bog, fruit and nuts were thrown onto the wet ground and children had to fetch them. He noted that this was an old tradition. Originally everybody had to walk out onto the wet ground in order to follow the boundary, but at the time of the recording in the $17^{\text {th }}$ century only children carried out this symbolic act, as it was important for them to know and experience the boundary. Hence, the Beating of the Bounds can be seen as the aboriginal dreamings and songlines of Dartmoor and Bodmin Moor.

So far the emphasis has been on the perception of the cultural landscape. But how was the past and natural landscape experienced? How did the inhabitants on the moors handle and explain the inexplicable? Did they know what was created by humans and what was natural? (Figs. 9-12) A connection between a place and a certain time of day is reflected in the folklore about the stone circles on Dartmoor. The stone circle at Greyweathers is said to turn around at sunrise, the Nine Stones at Bellstone dance at noon, and the eight rocks at Cosdon dance when the church bells ring. The Hurlers 

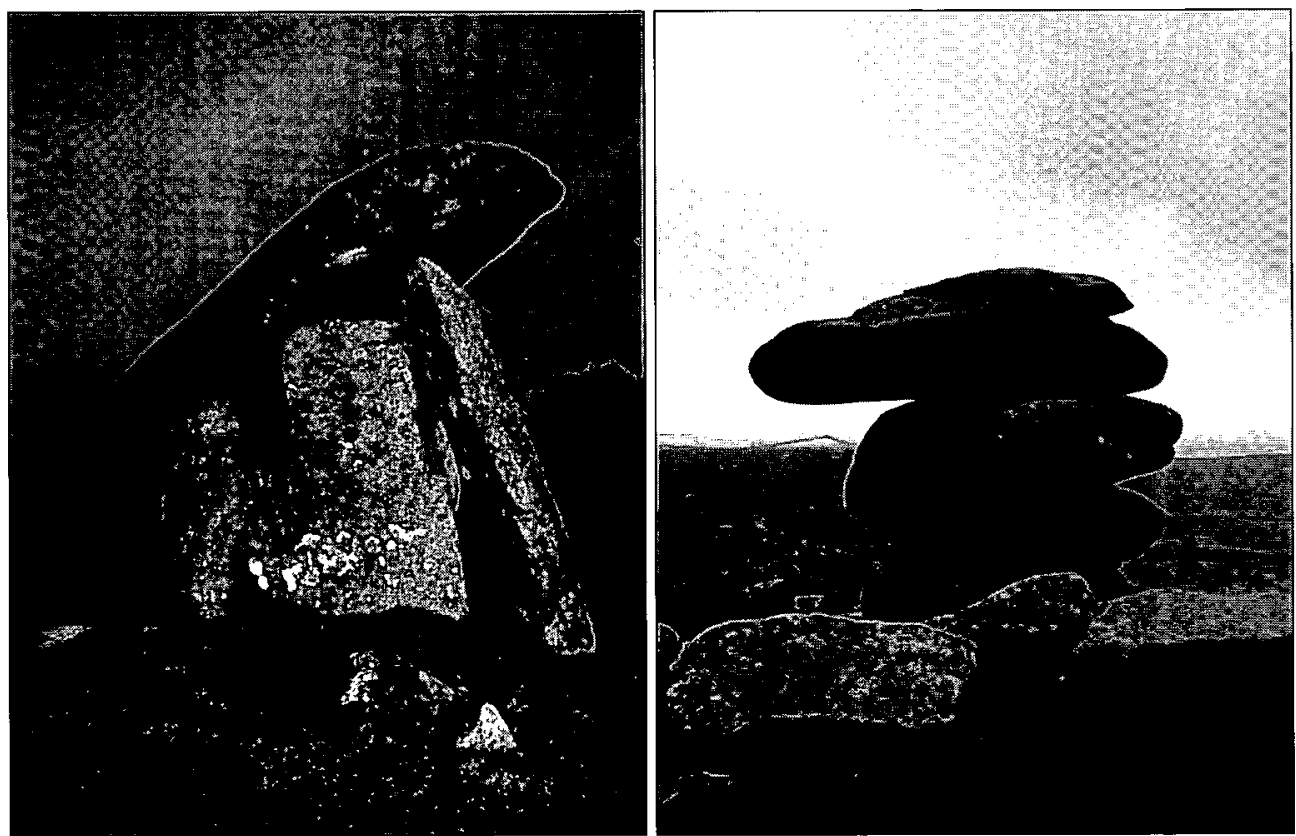

Fig. 9 - 10. Natural or man-made monuments? Trethevy Quoit and the Cheesewring, Bodmin Moor: Photo: K. Altenberg.

near Minions on Bodmin Moor are said to be the bodies of young people who became petrified when hurling on the Sabbath (Grinsell 1976). This explanation is of medieval origin and may reflect the fact that not everyone bothered to walk the long way to church on Sunday, and that there was a general belief that this was a great sin.

In a thought-provoking article from 1995, Nico Roymans discusses the Christianisation of pagan beliefs in the southern part of the Netherlands. Roymans argues that the early medieval church wanted to get rid of the pagan beliefs and cult places, as the one and only Christian faith must be worshipped in the church building. In order to achieve this, Christian propaganda was used to transform the pagan deities and mythical characters into 'negative antipodes to Christian values'. This process is called 'diabolisation' (Roymans 1995:15, 20). It is interesting to note that, whereas the Cornish hills and tors are often associated with giants, the Dartmoor ones are sometimes attributed to the devil (cf. Crossing 1997). This may reflect the fact that the missionary efforts of Christianity and the process of 'diabolisation' were stronger in Devon, which had a larger number of major ecclesiastical institutions than Cornwall.

Place-names and maps indicate the importance of rivers and water on Dartmoor. Folklore, sometimes of documented medieval origin, refers to alluring river spirits, and the cry of the river Dart is said to be heard in the evenings, calling out for a human heart (Crossing 1997:62). The common reference to the cry of the rivers and streams indicates an alertness to the surrounding landscape and shows that the audible experience, along with the visual, played a part in forming the perception of the world. It is 
also interesting that the cry of the river is time-specific and links a certain place in the local landscape with a certain time of the day, perhaps reflecting the importance of sound for orientation in a monotonous landscape.

The idea of stream spirits and moving stone circles thus seems to be related more to a way of dealing with the familiar landscape than a form of pantheism. The natural world clearly changes at sunrise, sunset and noon, and by linking the supposed activity of natural or prehistoric phenomena to these points in time one could explain and control their nature and purpose. In a similar way, the ringing of the church bells, triggering the movement of megaliths, indicated control over the unexplainable.
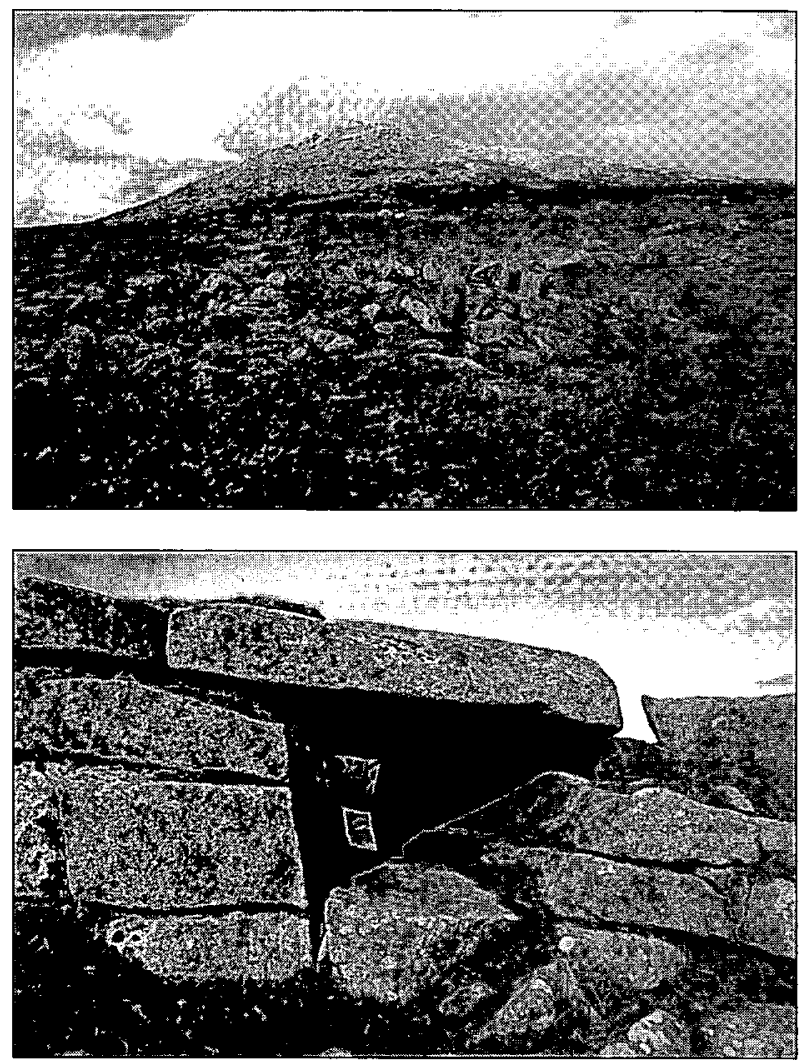

Fig. 11 - 12. Natural or man-made dwellings? Hut-circles and a natural formation, Roughtor: Bodmin Moor: Photo: K. Altenberg.

\section{CONCLUSION}

To sum up, the reaction of the medieval inhabitants on and around the moors to the natural features and prehistoric monuments reflects their attempts to:

- tame the features by giving them names and by erecting their own monuments (crosses and chapels) (perspective from the outside).

- explain their nature and existence through myths and folklore (perspective from the inside).

- incorporate them into their everyday life by taking away their threatening and dangerous aspects, by using them as boundary markers or for some other purpose (perspective from the inside).

I have tried to demonstrate how the multiple background of a certain context can be assessed by dissecting the mixed and to some extent superimposed sequence of events. By doing so, I have been able to discuss varying levels of social interaction (from the outside and from the inside) in the studied area. These levels should not be regarded as binary oppositions in a structuralist tradition, since useful concepts such as marginal 
and central are contextual and vary with the perspective. A certain context can thus carry aspects of marginality and centrality at the same time and is therefore better studied in terms of thick description rather than structural reading.

The experience of a medieval landscape must not be studied in isolation from the wider context of a regional, medieval society. By combining fieldwork, historical documents and ethnographic sources, one can detect differences between areas with apparent similarities and emphasise local variation. The strength of medieval archaeology, derived mainly from the wealth of available data, ought to be more extensively exploited in the creation of theoretical models for the study of the experience of medieval landscapes. There is more to the medieval landscape than is shown in excavation reports, and by adopting ideas developed within cultural geography, anthropology and to some extent prehistoric archaeology, medievalists can develop new approaches to the study of lost landscapes.

\section{English revised by Laura Wrang.}

\section{ACKNOWLEDGEMENTS}

Earlier drafts of this paper have been presented in seminars at Reading, Uppsala, Östersund and York. I am very grateful for the comments I received on these occasions. I would like to thank Stig Welinder; Roberta Gilchrist and Grenville Astill for their valuable comments on the present manuscript. The RCHME and the Cornwall Archaeological Unit granted permission to use Figure 2. A grant from the Medieval Settlement Research Group permitted fieldwork on Bodmin Moor and Dartmoor during September and October 1999.

\section{REFERENCES}

Allan, J. 1994. Medieval Pottery and the Dating of Deserted Settlements on Dartmoor. In: Griffiths, D. M. (Ed). The Archaeology of Dartmoor: Perspectives from the 1990 s. Devon Archaeological Society Proceedings no 52. Pp. 141-149.

Altenberg, K. Forthcoming. Current PhD studies at the Department of Archaeology, University of Reading. Andrén, A. 1989. Dörrar till förgångna myter. En tolkning av de gotländska bildstenarna. In: Andrén, A.

(Ed). Medeltidens födelse. Simposier på Krappenups borg 1. Krapperup. Pp. 287-319

Astill, G. \& Grant, A. (Eds). 1988. The Countryside of Medieval England. Oxford, Basil Blackwell.

Astill, G. 1997. An Archaeological Approach to the Development of Agricultural Technologies in Medieval England. In: Astill, G. \& Langdon, J. (Eds). Medieval Farming and Technology. The Impact of Agricultural Change in Northwest Europe. Leiden, Brill.

Aston, M. 1990. Segregation in Church. In: Shiels, W.J. \& Wood, D. (Eds). Women in the Church. Studies in Church History 27. Oxford, Blackwell.

Barrett, J. 1994. Fiagments from Antiquity. An Archaeology of Social Life in Britain. 2900-1200 BC. Oxford, Blackwell

Bender, B. , Hamilton, S. \& Tilley, C. 1997. Leskernick: Stone Worlds; Alternative Narratives; Nested Landscapes. Proceedings of the Prehistoric Society 63. Pp. 147-178.

Beresford, G. 1979. Three Deserted Medieval Settlements on Dartmoor: a report on the late E. Marie Minter's excavations. Medieval Archaeology 32. Pp. 175-183. 
Beresford, M. \& Hurst, J. 1990. Wharram Percy. Deserted Medieval Village. London. Batsford/English Heritage.

Bourdieu, P. 1977. Outline of a Theory of Practice. Cambridge, CUP.

Bradley, R. 1993. Altering the Earth. The Origins of Monuments in Britain and Continental Europe. Society of Antiquaries of Scotland Monograph Series 8. Edinburgh.

Burström, M. 1996. Other Generations' Interpretation and Use of the Past: the case of the Picture Stones on Gotland. Current Swedish Archaeology Vol. 4. Pp.21-40.

Butler, J. 1993. Bodies that matter - on the discursive limits of "sex". London \& New York, Routledge

- 1997. Excerpt from "Introduction" to Bodies That Matter: In: Lancaster, R.N. \& di Leonardo, M. (Eds). The Gender Sexuality Reader. Culture, History, Political economy. London \& New York, Routledge

Cassel, K. 1998. Från grav till gård. Romersk järnålder på Gotland. Stockholm Studies in Archaeology 16. Stockholms Universitet.

Crossing, W. 1912. Guide to Dartmoor: A Topographical Description of the Forest and Commons. The Western Morning News. Plymouth. (Reedited and printed by Mercer, I. 1993 and Peninsula Press, Newton Abbot.).

- 1994. Echoes of an Ancient Forest. Forest Publishing, Newton Abbot.

- 1997. Folklore and Ledgends of Dartmoor. Forest Publishing, Newton Abbot.

Dommasnes. L-H. 1987. Male/Female Roles and Ranks in Late Iron Age Norway. In: Bertelsen, R., Lillehammer, A. \& Naess, J. (Eds). Were They All Men? An Examination of Sex Roles in Prehistoric Society. Stavanger.

Du Maurier, D. 1936 (1978). Jamaica Inn. London, Gollancz

Dyer, C. 1989. "The Retreat from Marginal Land": The Growth and Decline of Medieval Rural Settlements. In: Aston, M.; Austin, D.; Dyer, C. (Eds). The Rural Settlements of Medieval England. Oxford, Basil Blackwell. Pp. 45-58.

- 1990. The past, the present and the future in medieval rural history. Rutal History vol. 1 no 1. Pp. 37-49.

Finberg, H.P.R. 1952. Childe's tomb. In: Hoskins, W.G. \& Finberg, H.P.R. Devonshire Studies. London, Jonathan Cape.

Fleming, A. 1999. Phenomenology and the Megaliths of Wales: A Dreaming Too Far? In: Oxford Journal of Archaeology 18 (2). Pp. 119-125.

Fleming, A. \& Ralph, N. 1982. Medieval settlement and land use on Holne Moor, Dartmoor: the landscape evidence. Medieval Archaeology 26. Pp. 101-137.

Foghill, M.A. 1954. Pastoralism on Dartmoor. Transactions of the Devonshire Association. 86. Pp. 89114.

Fox, H.S.A. 1991. Tenant Farmers and Farming: Devon and Cornwall. In: Miller, E. (Ed). The Agrarian History of England and Wales. Vol. iii 1348-1500. London, Longman. pp 722-743.

Gansum, T.; Jerpåsen, G. B. \& Keller, C. 1997. Arkeologisk landskapsanalyse med visuelle metoder. AmS-Varia 28. Museum of Archaeology. National Research Centre for Paleostudies and Conservation. Stavanger

Geertz, C. 1975. The Interpretation of Cultures. Selected essays by Clifford Geertz. London, Hutchinson. Gilchrist, R. 1999. Gender and Archaeology - contesting the past. London, Routledge.

Gansum, T; Jerpåsen, G. B. \& Keller, C. 1997. Arkeologisk landskapsanalyse med visuelle metoder. AmS-Varia 28. Museum of Archaeology. National Research Centre for Paleostudies and Conservation. Stavanger.

Gosden, C. 1994. Social Being and Time. Oxford. Basil Blackwell

Grinsell, L. 1976. Folklore of Prehistoric Sites in Britain. Newton Abbot, David and Charles.

- 1986. The Christianisation of Prehistoric and other Pagan Sites. Landscape History. Vol. 8. Pp. 27-37.

Harvey, D. 2000. Continuity, authority and the place of heritage in the Medieval world. Journal of Historical Geography, 26, 1. Pp. 47-59.

Henderson, C. 1935. Essays in Cornish History. Oxford, The Clarendon Press.

Herring, P. 1986. An Exercise in Landscape History. Pre-Norman and Medieval Brown Willy and Bodmin Moor; Cornwall. Unpublished M. Phil Thesis. University of Sheffield. Vol. 1-3.

Higuchi, T. 1983. The Visual and Spatial Structure of Landscape. Translated by Charles S. Terry. Cambridge Massachusetts, MIT Press. 
Hodder, I. 1986 (2nd ed.) Reading the Past. Current Approaches to Interpretation in Archaeology. Cambridge, CUP.

- 1987. The contribution of the long term. In: Hodder, I. (Ed). Archaeology as long-term History. Cambridge, CUP. Pp. 1-8.

Hooke, D. 1994. Pre-Conquest Charter-Bounds of Devon and Cornwall. Woodbridge, The Boydell Press.

Hull, P.L. (Ed). 1987. The Cartulary of Launceton Priory. Devon and Cornwall Record Society New Series, Vol. 30

Hunt, R. (Ed). 1871. Popular Romances of the West of England. London, John Camden Holten.

Johnson, N. \& Rose, P. 1994. Bodmin Moor An Archaeological Survey. Volume 1. The human landscape to c. 1800 . English Heritage Archaeological Report Series No 24. London, English Heritage and RCHM England.

Kowaleski, M. 1995. Local Markets and Regional Trade in Medieval Exeter. Cambridge, CUP.

Langdon, A. 1996. Stone Crosses in East Cornwall. Comish Cross Series No. 3. The Federation of Old Cornwall Societies, Padstow.

Lowenthal, D. 1985. The Past is a Foreign Country. Cambridge, CUP

Lynch, F. 1996. Review of Tilly 1994. A Phenomenology of Landscape. Places, Paths and Monuments. Landscape History 18. Pp. 84-85.

Maclean, J. 1868. Parochial and Family History of the Parish of Blisland. Nichols. London

Orme, N. (Ed). 1991. Unity and Variety. History of the Church in Devon and Cornwall. Ereter Studies in History. No 29. Exeter, EUP.

- 1992. Nicholas Roscarrock's Lives of the Saints: Cornwall and Devon. Devon and Cornwall Record Society New Series Vol 35.

Padel, O. 1985. Cornish Place-Name Elements. English Place Name Society Vol LVI/LVIl. Cambridge, CUP.

Parker Pearson, M. \& Richards, C. 1994. Ordering the World. Perceptions of Architecture, Space and Time. In: Parker Pearson, M. \& Richards, C. (Eds). Architecture and Order. London. Routledge. Pp. $1-37$.

Porteous, J.D. 1990. Landscapes of the Mind. Worlds of Sense and Metaphor. Toronto, University of Toronto Press.

Postan, M.M. 1972. The Medieval Economy and Society. An Economic History of Britain in the Middle Ages. London, Weidenfeld and Nicolson.

Roymans, N. 1995. The cultural biography of urnfields and the long term history of a mythical landscape. Archaeological Dialogues. Vol. 2 No 1. Pp. 2-24.

Taylor, C. 1992. Medieval rural settlement: changing perceptions. Landscape History vol. 14. Pp. 5-13. Thomas, J. 1996. Time, Culture and Identity. London. Routledge

Tilley, C. 1994. A Phenomenology of Landscape. Places, Paths and Monuments. Oxford and Providence, Berg Publishers

- 1995. Rocks as resources: landscapes and power. Cornish Archaeology No 34. Pp. 5-57.

- 1996. The powers of rocks: topography and monument construction on Bodmin Moor. World Archaeology. Vol. 28 (2). Sacred Geography. Pp. 161-176.

Welinder, S. 1992a. Människor och landskap. Uppsala. Aun 15.

- 1992b. Människor och Artefaktmönster. Uppsala Occasional Papers in Archaeology 5. Societas Archaeologica Upsaliensis.

Worth, 1944. The Tenants and Commoners of Dartmoor. Transactions of the Devonshire Association Vol. 76. Pp. 187-214.

Wylie, A. 1985. The reaction against analogy. In: Advances in archaeological method and theory, Vol. 8, M.B. Schiffer (Ed). New York, Academic Press. Pp. 63-111.

Zachrisson, T. 1996. Folkliga föreställningar. In: Burström, M. et al. Fornlämningar och Folkminnen. Riksantikvarieämbetet. Stockholm. Pp. 87-103. 
